\title{
Изучение населения сельских территорий в общеобразовательной школе
}

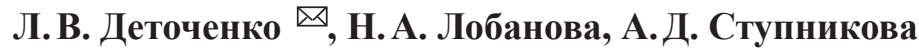 \\ Волгоградский государственный соџиально-педагогический университет, \\ Российская Федерачия \\ (400066, г. Волгоград, пр. им. В.И. Ленина, 27)
}

\begin{abstract}
Аннотация: Особенностью социально-экономической и демографической ситуации Волгоградской области является преобладающее количество сельских школ в образовательной структуре региона, на долю которых приходится около 57 \% от общего числа учреждений, реализующих программы общего образования. Однако в связи с недостаточным количеством часов, выделенных на изучение раздела «Население», примерной образовательной программой по географии не запланировано подробного изучения демографической ситуации сельских территорий. В свете требований действующих образовательных стандартов обязательным является формирование у обучающихся основ культуры исследовательской и проектной деятельности.

Цель статьи - выявить возможности изучения демографических процессов сельских территорий при выполнении проектных и исследовательских работ в школе, определить эффективность географических методов в развитии исследовательских умений учащихся.

Материаль и методы. Исходными материалами при написании статьи и организации исследовательской деятельности школьников стали данные официальной статистики - итоги переписей населения 2002 и 2010 годов, информация Росстата и территориального органа Федеральной службы государственной статистики Волгоградской области. Реализовать заявленную тематику позволяют три методических приема - картографирование расселения, обработка статистических данных, метод сравнения.

Результаты и обсуждение. Обоснована актуальность проблемы изучения демографических процессов сельских территорий при изучении географии в общеобразовательной школе. Показаны особенности применения картографического, статистического и сравнительного методов исследования при изучении демографических проблем сельских территорий на примере Камышинского муниципального района Волгоградской области. Выявлено влияние применения географических методов на развитие исследовательских умений школьников.

Заключение. Применение научных методов, специфичных для изучения демографических процессов, способствует развитию у школьников умений исследователя. Полученные результаты являются основой для выполнения учащимися проектно-исследовательских работ, связанных с изучением демографических процессов.
\end{abstract}

Ключевые слова: демографические процессы, учебно-исследовательская деятельность, методы географического исследования.

Для цитирования: Деточенко Л. В., Лобанова Н. А., Ступникова А.Д. Изучение населения сельских территорий в общеобразовательной школе // Вестник Воронежского государственного университета. Серия: География. Геоэкология, 2021, № 3, c. 91-96. DOI: https://journals.vsu.ru/geo/article/view/3606

\section{ВВЕДЕНИЕ}

Ведущие методисты-географы обращают особое внимание на изучение школьниками населенческих проблем своего края.
Особенности жизни населения синтезируют множество социально-географических аспектов своеобразие природных условий, истории заселения, специализации хозяйственной деятельности, культуры и быта.

(C) Деточенко Л.В., Лобанова Н. А., Ступникова А. Д., 2021

$\triangle$ Деточенко Лилия Валерьяновна, e-mail: Lillyad@rambler.ru

cc (i) Контент доступен под лицензией Creative Commons Attribution 4.0 License.

Вестник ВГУ, Серия: География. Геоэкология, 2021, № 3, 91-96 
Вопросы организации учебно-исследовательской деятельности учащихся стали предметом изучения учеными и школьными учителями и методистами $[4,6]$. Методические особенности организации учебно-исследовательской и проектной деятельности школьников на уроках географии и во внеклассной работе рассматриваются в публикациях И. В. Душиной, В.В. Николиной, Е. А. Таможней и другими. Учителями географии накоплен определенный опыт организации учебно-исследовательских и проектных работ школьников разной направленности - практико-ориентированные, информационные, творческие, экспериментальные, описательные, исследовательские проекты $[2,5]$. Однако, как показывает практика, при выполнении учебно-исследовательских и проектных работ «имеются сложности с определением методов научного исследования и их применением» [7]. Часто встречаются случаи несоответствия заявленных методов исследования и теми методами, которыми непосредственно пользуются авторы при подготовке конкурсных работ. И это при том, что метод является центральным элементом всей системы методологии. Методы географического исследования (картографический, статистический, сравнительный, геоинформационный, наблюдения) находят своё отражение как базовые способы познания мира современного человека. $\mathrm{C}$ их помощью знания преобразуются в исследовательские умения.

Научные основы в области изучения сельского расселения заложены С. А. Ковалевым, а Ю. Г. Саушкин предложил методику изучения сельского расселения. В самое последнее время проблемам демографического развития сельских территорий посвящены труды А.А. Чибилева (мл.), Е.А. Семенова, Д.В. Григоревского [8], А. И. Алексеева, С.Г. Сафронова [1] и других. Население Волгоградской области рассматривается в работах Л.В. Деточенко и Н. А. Лобановой [3].

\section{МАТЕРИАЛЫ И МЕТОДЫ}

Исходными материалами при написании статьи и организации исследовательской деятельности школьников стали данные официальной статистики - итоги переписей населения 2002 и 2010 годов, информация Росстата и территориального органа Федеральной службы государственной статистики Волгоградской области. Реализовать заявленную тематику позволяют три методических приема - картографирование расселения, обработка статистических данных, метод сравнения.

\section{РЕЗУЛЬТАТЫ И ОБСУЖДЕНИЕ}

Цель статьи - выявить возможности изучения демографических процессов сельских территорий при выполнении проектных и исследовательских работ в школе, определить эффективность географических методов в развитии исследовательских умений учащихся.

Рассмотрим методы исследования, необходимые учащимся при изучении демографических проблем сельских поселений на примере Камышинского муниципального района Волгоградской области.

В Камышинском муниципальном районе на 01.01.2020 г. проживало 39,6 тыс. человек, что составляет 1,6\% населения Волгоградской области. Район занимает лидирующее 4-е место по численности населения среди 32 муниципальных районов области. Среди 48 сельских поселений крупнейшим по числу жителей является Мичуринское, где проживает 5390 человек, что составляет $13,4 \%$ населения района. Сельское поселение Чухонастовское относится к малочисленным поселениям. Число жителей равно 529 человек или $1,3 \%$ населения района.

Использование картографического метода исследования позволяет выявить неравномерность в расселении населения на территории Камышинского района. По среднему показателю плотности населения - 11 чел. на км² район уступает в 2 раза Волгоградской области (23 чел. на $\mathrm{\kappa M}^{2}$ ). Наибольшее число поселений района расположены в более благоприятных природно-климатических условиях, а именно: в зоне относительно плодородных каштановых почв с высокой степенью распаханности (от 50 до $80 \%$, местами и более). Поселения тяготеют к балкам или к долинам рек. Здесь чаще расположены сельские населенные пункты с числом жителей более 100 человек. На водоразделах находится разреженная сеть мелких сёл.

При изучении населения учащиеся впервые знакомятся со статистическим методом исследования, имеющим определённые особенности. Для освоения школьниками методики работы со статистическими материалами, они должны иметь представление о специфике этой информации, заключающейся в разных видах отображений цифровых показателей, служащих разным целям: одни показывают динамику явлений, другие - структуру и связи, третьи - состав изучаемых объектов и явлений.

Особый интерес представляет изучение сельских населенных пунктов по численности про- 
живаемого населения. На основе использования статистического метода исследования учащимися проведен анализ сельских населённых пунктов по их людности.

Используя результаты Всероссийской переписи населения 2010 года, установлено - 37\% жителей района проживает в населенных пунктах с людностью 101-200 и 201-500 человек; $15 \%$ с численностью 501-1000 человек; 27\% живут в селах, где число жителей свыше $1000 ; 6 \%$ поселений имеют от 51 до 100 жителей и $15 \%$ до 50 человек.

Процессы естественного движения населения Камышинского района соответствуют процессам воспроизводства населения России и Волгоградской области. С использованием статистического и сравнительного методов исследования имеется возможность выявления особенностей естественного движения населения и разработки прогноза изменения численности населения района.

С 1992 года в районе сложилась тенденция суженного воспроизводства населения, которая прерывалась лишь в 2013 году, когда был представлен простой подтип воспроизводства, с показателем естественного прироста 0,0\%. В 2000-е годы наблюдается улучшение ситуации с воспроизводством населения. Так, в 2013 году показатель коэффициента рождаемости достиг максимального значения 13,6\%. Среди основных причин роста рождаемости необходимо отметить следующие: вступление в детородный возраст многочисленного поколения, родившегося в середине 1980-х годов, развертывание государством активной демографической политики, направленной на стимулирование рождаемости.

Несмотря на относительно благополучную ситуацию, сложившуюся в Камышинском районе по показателям рождаемости с 2011 по 2016 годы $(13,6 \%)$, к концу второго десятилетия 2000-х годов произошло снижение рождаемости. Причина - вступление в репродуктивный возраст малочисленного поколения 1990-х годов. К 2017 году рождаемость уменьшилась до 8,4\%, а уровень смертности достиг 13,7\% . В 2019 году коэффициент естественного прироста населения в районе имеет отрицательное значение - минус $6,1 \%$.

Наряду с изучением вопросов естественного движения населения, особый интерес представляет характеристика половозрастной и этнической (национальной) структур населения.
В половом составе в Камышинском районе преобладает мужское население над женским. Напротив, в Волгоградской области и в других сельских муниципальных районах существенно преобладает женское население. На 1000 женщин в Камышинском районе приходится 1006 мужчин. Численный перевес мужского населения над женским связан с преобладанием мужчин в возрастных группах моложе трудоспособного и трудоспособного возраста $-80,4 \%$ от общей численности мужчин. Тогда как в общей численности женщин, доля женщин этих возрастных групп составляет $61,3 \%$. Мужское население превышает женское в этих возрастных группах на 4036 чел.

Перевес мужского населения проявляется с момента рождения ребенка - на 100 девочек рождается 105-107 мальчиков. Численный перевес мужского населения над женским в районе сохраняется до 54 лет.

Доля женщин в численности населения растет с увеличением возраста. Так, в возрастной группе старше трудоспособного возраста наблюдается двукратное превышение женского населения. Такое значительное преобладание женщин в данной возрастной группе объясняется большим разрывом в средней продолжительности жизни мужчин и женщин.

Для развития исследовательского мышления школьников важным является установление причинно-следственной связи между возрастной структурой населения и естественным движением населения. Старение населения в районе, увеличение численности населения старших возрастных групп приводит к увеличению значений показателей смертности. Уменьшение доли молодых возрастов в численности населения приводит к уменьшению показателей рождаемости.

Анализ национального состава результатов Всероссийской переписи населения 2010 года, свидетельствует о том, что в районе сложился сложный этнический состав, представленный 48 народностями. По численности населения преобладает титульный этнос - русские, доля которых составляет 87,59\%. К многочисленным этносам, проживающим на территории района, относятся также немцы - $4,43 \%$, украинцы - $2,0 \%$, езиды $1,39 \%$, армяне $-0,86 \%$.

Применение сравнительного метода исследования позволяет выявить изменения этнической ситуации, произошедшей в Камышинском районе с момента переписи населения 2002 г. Про- 
ведение систематизации фактов, их группировка в определенной системе с последующим выявлением сходства или различия между ними, позволяет произвести типологию и таксономию, пространственную группировку и периодизацию.

Изменение численности этнических групп населения, произошедшие с момента предыдущей переписи населения 2002 года позволяет выделить две группы: увеличивших свою долю в общей численности населения района и уменьшивших ее. Первая этническая группа представлена русскими (с 84,1 до 87,59\%), езидами (с 0,98 до 1,39\%), армянами (с 0,63 до 0,86\%), азербайджанцами (с 0,23 до 0,37\%), цыганами (с 0,2 до 0,29\%). У большинства народов этой группы увеличение численности населения связано с более высоким естественным приростом населения. На увеличение доли русских в общей численности населения района повлиял миграционный приток из районов области и других регионов России [3].

Вторая этническая группа представлена народами, сократившими свою долю в общей численности населения района - украинцами (с 3,19\% до 2,0\%), немцами (с 6,98 до 4,43\%), татарами (с 0,7 до 0,57\%), белорусами (с 0,45 до 0,34\%). Низкие темпы естественного прироста и влияние процессов реэмиграции населения повлияли на уменьшение численности этих народов.

\section{ЗАКЛЮЧЕНИЕ}

Таким образом, происходящие в сельских районах демографические процессы предоставляют обширный материал для выполнения проектно-исследовательских работ, формированию у школьников основ культуры исследовательской и проектной деятельности. Применение методов научного исследования, специфичных для изучения демографических процессов, способствует развитию у учащихся исследовательских умений, формируя исследовательский тип мышления. Наиболее ценным образовательным результатом будет умение школьников использовать источники географической информации и применять методы географического исследования в повседневной жизни.

\section{СПИСОК ЛИТЕРАТУРЫ}

1. Алексеев А.И., Сафронов С. Г. Изменение сельского расселения в России в конце XX - начале XXI века // Вестник Московского университета, 2015, № 2, c. 66-79.

2. Владимирова С.В. Научно-исследовательская деятельность по географии как средство развития интеллектуального потенциала обучающихся // Becmник ВГУ. Серия: География. Геоэкология, 2012, № 1, c. $145-148$.

3. Деточенко Л.В., Лобанова Н.А. Демографическая ситуация Волгоградской области на рубеже XX-XXI вв. // Известия Волгоградского государственного педагогического университета, 2018, № 2 (125), c. 190-196.

4. Леонтович А. В. К проблеме исследований в науке и в образовании // Развитие исследовательской деятельности учащзихся, 2001, с. 33-37.

5. Резьникова А.И., Сафонова Н.С. Формирование интеллектуальных и творческих способностей учащихся при проведении научных исследований по географии и биологии в полевых условиях // Becmник ВГУ. Серия: География. Геоэкология, 2012, № 1, c. $149-152$.

6. Савенков А.И. Содержание и организация исследовательского обучения школьников. Москва: ИФ «Сентябрь», 2003. 235 с.

7. Ступникова А.Д., Деточенко Л.В. Возможности курса «Организация внеклассной деятельности учителя географии» в развитии способности руководить научно-исследовательской деятельностью обучающихся // Материалы Всероссийской научно-практической конференции «Современное географическое образование: проблемы и перспективы развития», 2016, с. 177-179.

8. Чибилев А.А. (мл), Семенов Е.А., Григоревский Д.В. Проблемы и специфика сельского расселения в Оренбургской области // Вестник Воронежского государственного университета. Серия: География. Геоэкология, 2016, № 1, с. 34-38

Конфликт интересов: Авторы декларируют отсутствие явных и потенциальных конфликтов интересов, связанных с публикацией настоящей статьи.

Поступила в редакциию 28.12.2020 Принята к публикаичи 03.09.2021 


\title{
Studying the Rural Areas Population in Secondary School
}

\author{
L.V. Detochenko ${ }^{凶}$, N.A. Lobanova, A.D. Stupnikova \\ Volgograd State Social and Pedagogical University, Russian Federation \\ (27, V.I. Lenin Ave., Volgograd, 400066)
}

\begin{abstract}
The peculiarity of socio-economic and demographic situation in Volgograd Oblast is the predominant number of rural schools in the educational structure of the region, which account for about $57 \%$ of the total number of institutions implementing general education programmes. However, due to the insufficient number of hours allocated for studying the section "Population", the model educational programme on geography does not plan a detailed study of the demographic situation in rural areas. In the light of the requirements of the current educational standards, it is obligatory for students to form the basics of a culture of research and project activities.

The aim of the article is to identify the possibilities of studying the demographic processes of rural areas in project and research work at school and to determine the effectiveness of geographical methods in the development of students' research skills.

Materials and methods. The source materials for writing the article and organizing research activities of schoolchildren were the data of official statistics - the results of the 2002 and 2010 censuses, information of Rosstat and the territorial body of the Federal State Statistics Service of the Volgograd Oblast. Three methodological techniques allow to implement the declared subject: settlement mapping, processing of statistical data, the method of comparison.

Results and discussion. The urgency of the problem of studying the demographic processes of rural areas in the study of geography in secondary schools is substantiated. It shows the peculiarities of applying cartographic, statistical and comparative methods of research in the study of demographic problems of rural areas on the example of Kamyshinsky municipal district of Volgograd region. The influence of the use of geographical methods on the development of research skills of schoolchildren is revealed.

Conclusion. The application of scientific methods specific to the study of demographic processes contributes to the development of students' research skills. The results obtained provide a basis for students to carry out project-research activities related to the study of demographic processes.
\end{abstract}

Key words: demographic processes, educational and research activities, geographical research methods.

For citation: Detochenko L. V., Lobanova N.A., Stupnikova A. D. Studying the Rural Areas Population in Secondary School. Vestnik Voronezskogo gosudarstvennogo universiteta. Geografia geoekologia, 2021, no. 3, pp. 91-96. (In Russ.) DOI: https://journals.vsu.ru/geo/article/view/3606

\section{REFERENCES}

1. Alekseev A.I., Safronov S. G. Izmenenie sel'skogo rasseleniya v Rossii v kontse XX - nachale XXI veka [Changes in rural settlement in Russia at the end of the XX - early XXI century]. Vestnik Moskovskogo universiteta, 2015, no. 2, pp.66-79. (In Russ.)

2. Vladimirova S. V. Nauchno-issledovatel'skaya deyatel'nost' po geografii kak sredstvo razvitiya intellektual'nogo potentsiala obuchayushchikhsya [Research activities in geography as a means of developing the intellectual poten- tial of students]. Vestnik VGU. Seria: Geografia. Geoekologia, 2012, no. 1, pp. 145-148. (In Russ.)

3. Detochenko L.V., Lobanova N.A. Demograficheskaya situatsiya Volgogradskoy oblasti na rubezhe XXXXI vv. [The demographic situation of the Volgograd region at the turn of the XX-XXI centuries.]. Izvestiya Volgogradskogo gosudarstvennogo pedagogicheskogo universiteta, 2018, no. 2 (125), pp.190-196. (In Russ.)

4. Leontovich A.V. K probleme issledovaniy v nauke i $v$ obrazovanii [To the problem of research in science

(C) Detochenko L. V., Lobanova N.A., Stupnikova A. D., 2021

Lilia V. Detochenko, e-mail: Lillyad@rambler.ru 
and in education]. Razvitie issledovatel'skoy deyatel'nosti uchashchikhsya, 2001, pp. 33-37. (In Russ.)

5. Rez'nikova A. I., Safonova N. S. Formirovanie intellektual'nykh i tvorcheskikh sposobnostey uchashchikhsya pri provedenii nauchnykh issledovaniy po geografii i biologii v polevykh usloviyakh [Formation of intellectual and creative abilities of students in conducting scientific research on geography and biology in field conditions]. Vestnik VGU. Seria: Geografia. Geoekologia, 2012, no. 1, pp. 149-152. (In Russ.)

6. Savenkov A. I. Soderzhanie i organizatsiya issledovatel'skogo obucheniya shkol'nikov [Content and organization of research learning schoolchildren]. Moscow: IF «Sentyabr'», 2003. 235 p. (In Russ.)

7. Stupnikova A.D., Detochenko L. V. Vozmozhnosti kursa «Organizatsiya vneklassnoy deyatel'nosti uchitelya geografii» v razvitii sposobnosti rukovodit' nauchno-issledovatel'skoy deyatel'nost'yu obuchayushchikhsya [The

Деточенко Лилия Валерьяновна

кандидат географических наук, доцент кафедры географии, геоэкологии и методики преподавания географии Волгоградского государственного социально-педагогического университета, г. Волгоград, Российская Федерация, ORCID: 0000-0002-9483-6399, e-mail: Lillyad@ rambler.ru

\section{Лобанова Наталья Анатольевна}

кандидат географических наук, доцент кафедры географии, геоэкологии и методики преподавания географии Волгоградского государственного социально-педагогического университета, г. Волгоград, Российская Федерация, ORCID: 0000-0002-9763-1006, e-mail: natlob66@ yandex.ru

\section{Ступникова Антонина Дмитриевна}

кандидат педагогических наук, доцент кафедры географии, геоэкологии и методики преподавания географии Волгоградского государственного социально-педагогического университета г. Волгоград, Российская Федерация, ORCID: 0000-0002-7090-3673, e-mail: Stupnikovaa@mail.ru facilities of the course "Organization of extracurricular activities of teacher of geography" in the development of the ability to manage research activities of students]. Materialy Vserossiyskoy nauchno-prakticheskoy konferentsii "Sovremennoe geograficheskoe obrazovanie: problemy i perspektivy razvitiya», 2016, pp. 177-179. (In Russ.)

8. Chibilev A.A. (ml), Semenov E.A., Grigorevskiy D. V. Problemy i spetsifika sel'skogo rasseleniya v Orenburgskoy oblasti [Problems and specifics of rural settlement in the Orenburg region]. Vestnik Voronezhskogo gosudarstvennogo universiteta. Seria: Geografia. Geoekologia, 2016, no. 1, pp. 34-38. (In Russ.)

Conflict of interests: The authors declare no information of obvious and potential conflicts of interest related to the publication of this article.

Received: 28.12.2020

Accepted: 03.09.2021

Lilia V. Detochenko

Cand. Sci. (Geogr.), Associate Professor of the Department of Geography, Geoecology and Methods of Teaching Geography of the Volgograd State Socio-Pedagogical University, Volgograd, Russian Federation, ORCID: 0000-00029483-6399, e-mail: Lillyad@rambler.ru

Natalya A. Lobanova

Cand. Sci. (Geogr.), Associate Professor of the Department of Geography, Geoecology and Methods of Teaching Geography of the Volgograd State Socio-Pedagogical University, Volgograd, Russian Federation, ORCID: 0000-00029763-1006, e-mail: natlob66@yandex.ru

Antonina D. Stupnikova

Cand. Sci. (Pedagog.) Sci., Associate Professor of the Department of Geography, Geoecology and Methods of Teaching Geography of the Volgograd State Social and Pedagogical University, Volgograd, Russian Federation, ORCID: 0000-0002-7090-3673, e-mail: Stupnikovaa@ mail.ru 